\title{
Economies of Scale on the Municipal Level: Fact or Fiction in the Czech Republic?
}

\author{
Lenka Matějová1, Juraj Nemec ${ }^{2}$, Milan Křápek ${ }^{3}$, Daniel Klimovskýr
}

\begin{abstract}
Many countries have carried out extensive amalgamation-related territorial reforms at the level of local self-government and created relatively large municipalities. The Czech Republic is one of the few remaining European countries with a fragmented territorial structure. There is a lot of discussion in the country about the need for amalgamation, but this discussion is mainly based on political arguments rather than on empirical evidence about the feasibility of amalgamation and its potential to improve local government performance. This paper analyses economies of scale on the local level as a factor that should be reflected in debates about the pros and cons of amalgamation in the Czech Republic. To add to the existing knowledge about the reality of economies of scale on the municipal level in the Czech Republic, we processed the municipal costs of three selected areas on a representative sample of municipalities in the South Moravian Region. The analysis showed that economies of scale can be identified for collecting local fees and for pre-school and elementary education, but not for local administration. Our results suggest that the existence of too small municipalities in the Czech Republic results in inefficiencies and should be addressed.
\end{abstract}

\section{Keywords:}

economies of scale, territorial reform, public service, local self-government, local fees, education, local administration, Czech Republic

1 Assistant, Department of Public Economics, Faculty of Economics and Administration, Masaryk University, Brno, Czech Republic.

2 Professor, Department of Public Economics, Faculty of Economics and Administration, Masaryk University, Brno, Czech Republic.

3 Assistant Professor, Private College of Economic Studies, Czech Republic.

4 Associate Professor, Department of Political Science, Faculty of Arts, Comenius University, Bratislava, Slovakia. 


\section{Introduction}

Local self-governments are an integral subsystem of democratic regimes, responsible for local development and the delivery of a large amount of local public services. Their important role in modern society is stressed in the main economic theories, including Oates's decentralisation theorem (Oates 1972, 1999) and the idea of fiscal federalism (Tiebout 1956; Musgrave and Musgrave 1989). Local self-governments are codified on the political level (European Charter of Local Self-government). However, the patterns of local self-government differ, with national variations and specific characteristics related to history and the current will to decentralise.

One of the major differences among local self-governments is the size of municipalities. Some countries, such as Sweden and Latvia, are well known for amalgamated local-government systems; other countries, including the Czech Republic and Slovakia, have a high number of very small municipalities. This situation reflects the fact that the question of the "optimum size of municipalities" is a typical "wicked problem" and does not have an absolute answer (see, for example, Dahl and Tufte 1973; Nielsen 1981; King 1984; Mouritzen 1989; Newton 1982; Bours 1993; Sharpe 1995; Hampl and Müller 1998; Goldsmith and Rose 2000; Denters 2002; Rose 2002; Swianiewicz 2002; Baldersheim and Rose 2008; Faulk and Hicks 2011; Keating 1995).

Smaller local units may stimulate a higher level of participation of citizen in local issues, but most economists assume that such small size causes higher unit costs of public-service delivery. Local governments that are too small are expected to suffer from a lack of resources and a lack of competence and expertise; fragmentation thus probably increases the direct and indirect costs of public-service delivery.

Because efficiency is more and more important for national governments, several European countries decided on a process of territorial consolidation or amalgamation. In Denmark, the number of municipalities decreased from almost 280 to 98 between 2000 and 2010; in Finland, from 436 to 342; and the Netherlands reduced the number of municipalities from 400 to 150 (Baldersheim and Rose 2008). This phenomenon is not limited to Europe. Municipal amalgamations have also taken place in Australia (Dollery et al. 2008) and in several Canadian provinces (Kushner and Siegel 2003).

The Czech Republic remains an exception. The core reason for this is a lack of political will to change the territorial structure of the country. However, there is also little empirical evidence of economic arguments for the necessity and feasibility of reform. The key question of whether the amalgamation of municipalities could improve the efficiency of local service delivery and if economies of scale really exist has been addressed by only a very few recent studies. 
The aim of this paper is to test the existence of economies of scale at the local self-government level in the Czech Republic in three selected areas and, on the basis of the findings, to formulate inputs to the discussion about future reform options for local self-government in the Czech Republic.

The analysis in this paper attempts to extend the knowledge about problem of economies of scale in the public sector and to include itself among the few studies that deal with the topic in the Czech Republic. It also contributes to the discussion on using the principle of economies of scale at the municipal level. The specificity of the Czech case is the high territorial fragmentation of municipalities and the large share of small municipalities with up to 500 inhabitants.

\section{Using the theory of economies of scale in the Czech Republic}

\subsection{Economies of scale and the "optimum size" of municipalities}

Territorial reforms are connected with debates on the advantages and disadvantages of small and large local self-government units. These sizes are most frequently expressed in terms of the population number, because this indicator relates directly to the consumers of locally provided services and costs, which are first and foremost a function of the number of customers/inhabitants (see, for example, Swianiewicz 2002). Summaries of these theoretical discussions may be found, for example, in Sharpe (1995) and Keating (1995). Table 1 presents a list of the core arguments supporting small or large population sizes for local self-government that appear in discussions about territorial fragmentation or about systems with fewer and larger local units.

While the system of many small autonomous units is usually supported by arguments regarding the functioning of democratic principles in the municipality, the arguments for larger units relate mostly to economics, namely the possibility of more efficient public-service delivery and the capacity for development. For these reasons, many studies dealing with the trade-off between small and large local selfgovernment units focus on finding the optimum size for efficient public-service delivery using the theory of economies of scale.

Economies of scale is the theory of the relationship in the scale of the use of a properly chosen combination of all productive inputs and the rate of the output of the enterprise. The importance of economies of scale for large organisations was first brought to public attention by Stigler (1958) and Coase (1937). It is also applicable to the public sector and to local governments, when local self-government is seen as a production unit (Hirsch 1959; Sawyer 1991; Boyne 1995; Houlberg 2010; Faulk and Hicks 2011). 


\section{Table 1}

Arguments supporting small and large population sizes of local-self government

\begin{tabular}{|c|c|}
\hline Small population municipalities & Large population municipalities \\
\hline \multicolumn{2}{|c|}{ Democracy-related arguments } \\
\hline $\begin{array}{l}\text { - Close citizen participation in local policy } \\
\text { - Direct contact with politicians and } \\
\text { municipal officers } \\
\text { - Support for local autonomy } \\
\text { - Better accountability for politicians } \\
\text { - Satisfaction with local government } \\
\text { - Better fulfilled political ideas } \\
\text { - Better human relationships }\end{array}$ & $\begin{array}{l}\text { - Higher total non-electoral participation } \\
\text { (voluntary organisations) } \\
\text { - Better representation of various minority } \\
\text { groups } \\
\text { - Better accessibility of local administration } \\
\text { - More competent candidates for elected } \\
\text { functions; wider base }\end{array}$ \\
\hline \multicolumn{2}{|c|}{ Economy-related arguments } \\
\hline $\begin{array}{l}\text { - Easier flow of information to inhabitants } \\
\text { - Less bureaucracy } \\
\text { - Lower level of corruption } \\
\text { - Better coordination of management } \\
\text { - innovation } \\
\text { - Better implemented individual } \\
\text { preferences of citizens } \\
\text { - Lower administrative costs } \\
\text { - Higher competition for financial resources } \\
\text { among local self-governments }\end{array}$ & $\begin{array}{l}\text { - Economies of scale of public services } \\
\text { delivery } \\
\text { - Better specialisation and professional } \\
\text { bureaucracy } \\
\text { - Lower costs related to spillovers } \\
\text { - Reduction of bureaucracy expenditure } \\
\text { - More financial and employment } \\
\text { opportunities for inhabitants } \\
\text { - Sufficient personal, economic and } \\
\text { political resources } \\
\text { - More ambitious development projects } \\
\text { - Better technical infrastructure }\end{array}$ \\
\hline
\end{tabular}

Source: Authors, according to various sources

In economic theory, the different types of relationships between inputs and outputs are expressed in terms of returns to scale. Returns to scale essentially refers to how output reacts to increases or decreases in all of the inputs taken together (Dollery et al. 2008). Economies of scale transform this relationship into monetary values. Increasing returns to scale translate into increasing economies of scale, with the average cost of a unit of output falling; constant returns to scale translate into constant economies of scale, with the average cost of a unit of output remaining the same; and decreasing returns to scale translate into diseconomies of scale, with the average cost of a unit of output rising. The normal average cost curve is U-shaped (see Figure 1) because economies of scale reverse after the threshold of the optimal size of an organisation is reached, following which unit costs rise and diseconomies of scale occur. Thus, marginal costs are larger than average costs (Boyne 1995).

The concept of economies of scale is often used as an argument for structural reforms in the public sector, such as amalgamating small municipalities into larger municipalities and for evaluating territorial reforms of local governments. The main argument is that if each municipality produces relatively comparable services and if there are substantial aggregate economies of scale, then a system with numerous small municipalities will have higher expenditures for the same level and composition of output than a system with fewer larger local governments (Dollery 
and Fleming 2006). Amalgamated municipalities could lower their costs and cut taxes or fees without compromising the level of services, or keep the same level of costs while providing better services to their residents. Larger local governments could also improve the performances of their staff and lower the administrative costs of regulating the municipalities' activities by the central government (Fox and Gurley-Calvez 2006).

\section{Figure 1}

Economies and diseconomies of scale
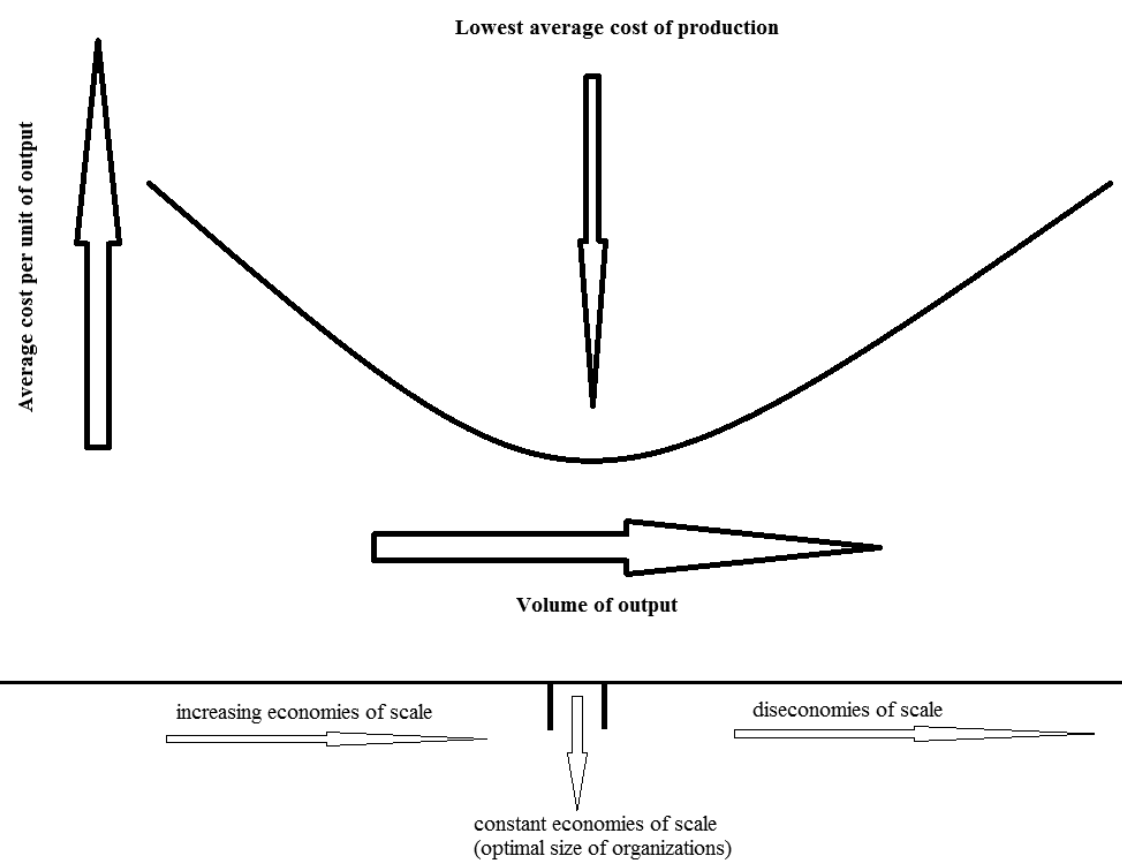

Source: Authors, based on Allan (2003)

The critics of this concept usually provide three reasons why these assumptions should not apply: climatic and demographic characteristics, service quality and local preferences. The problem with these three arguments lies in their immeasurability. Unfavourable climatic conditions can be very difficult to objectify and thereby determine their impact on the cost of local public-service delivery. Similarly, the quality of services in the public sector and related local preferences are very subjective and hardly measurable (see, for example, Löfler 2002; Bovaird and Löffler 2003). The public services that are provided by the public sector are usually not physical in nature. This means that their quality cannot be associated with tan- 
gible and measurable properties. The concept of economies of scale assumes similar comparable outputs (cost minimisation method), and if outputs are different, as suggested by many critics, the method is not an appropriate efficiency measure.

However, the most important criticism of the assumption that larger municipalities are more cost-effective is that there is rather limited empirical evidence about the real existence of savings on the local-government level due to larger volumes of production. Relatively large samples of studies have focused on verifying the existence of economies of scale in principle at the local-government level. Most of these studies used expenditure models with per-capita expenditure as the dependent variable and population size as the independent variable. The first studies were initiated in the 1970s and 1980s. Many of these analyses were done for conditions in Great Britain (see, for example, Alt 1971; Davies 1971; Foster et al. 1980) and the United States (Appelbaum and Follett 1978; Schofield 1978; Hutcheson and Prather 1979). Most often, these studies analysed the total administration expenditure, education, social services and road expenditure. In the 1990s, the first studies were created for the Danish institutional context (Mouritzen 1991; Houlberg 1995; Houlberg and Møller 2001), especially with regard to local-government reforms that had been carried out over the last 20 years. Empirical analyses were also performed for Australia, Canada, Switzerland, Spain, France, Germany and Israel.

There have been very few studies testing the existence of economies of scale at the local self-government level in the Czech Republic. One of the first attempts was the calculation of the administrative costs of the collection of local taxes and fees by Vítek and Pavel (in Pudil et al. 2004). Recently, the main focus has been on waste management (see, for example, Soukopová 2016) and on other selected local services (see, for example, Soukopová et al. 2014).

\subsection{Territorial structure of local self-governments in the Czech Republic}

The Czech Republic has a two-tier system of local self-government. Higher territorial self-administrative units are regions; local self-government units are municipalities. Both levels are responsible for their own and delegated competencies.

In accordance with the definition by Swianiewicz (2014), the Czech Republic is a country in which municipalities have extensive powers in the provision of public services and in territorial development, but limited financial autonomy. The main activities of the municipality include municipal administration (functioning of municipality authorities, property care and fulfilling statutory legal obligations), the performance of state administration in the delegated competence, the implementation of development activities and the provision of public services (either under its own power or through delegation to or cooperation with other private individuals). Some public services, primarily social-assistance and care services, are often provided by the non-profit sector on the basis of financial support from public funds. 
The territorial structure of the municipalities in the Czech Republic gained its current appearance in the $17^{\text {th }}$ century. In the beginning of the $20^{\text {th }}$ century, many towns were absorbed by surrounding municipalities because of their natural expansion; this led to the reduction of the number of municipalities to 11,000 . Over $83 \%$ of these municipalities had fewer than 1,000 inhabitants (Galvasová et al. 2007). Massive and centrally orchestrated waves of amalgamation of municipalities took place in 1960 . Almost $20 \%$ of all municipalities were abolished and administratively merged with their larger neighbours; between 1970 and 1989, the number of municipalities was reduced by almost $50 \%$ (to 4,800 municipalities). However, after 1990 , the number of municipalities rose by almost $50 \%$ (from 4,120 to 6,250 ). Since 2001 , the total number of municipalities has stabilised at about 6,250.

The settlement structure is dense, consisting of a large number of villages, townships, and small towns. There are relatively few medium and large cities. According to the data from the Czech Statistical Office (2016), the absolute majority of municipalities are villages with a very small population size: $77.1 \%$ of the municipalities have fewer than 1,000 inhabitants; almost $24 \%$ of the municipalities have fewer than 200 inhabitants. The average size of the villages is 1,685 inhabitants, and the median size is 425 inhabitants. Only 597 municipalities have a "city" status. There are only 19 cities that have more than 50,000 inhabitants.

The fragmented settlement structure in the Czech Republic is accompanied by a fragmented structure of local authorities. According to the Act on Municipalities, even very small villages have their own elected mayor and assembly, and every such village must provide at least basic public services, such as public administration, public lighting, waste management and community development. In the Czech Republic, there are 5,004 municipalities with basic competence; of these, 3,445 municipalities have fewer than 500 inhabitants.

This fragmented structure has an impact on the implementation of delegation and on independent competence. In 2004, the OECD pointed out that municipal fragmentation is a strong obstacle to better governance and efficient delivery of policies because municipal self-government is not accompanied by measures based on the principle of "functional areas" (OECD 2004). According to Swianiewicz (2010) it quickly became apparent that territorial fragmentation was a major barrier to the decentralisation and effective functioning of the local-government system.

\section{Data and Methodology}

This paper tests the existence of economies of scale at the local-government level in three selected areas - administrative costs of local taxation (collection of local taxes and fees), general administrative costs and preschool and elementary education. The selection of these areas is intentional. First, we tested if the relatively old data about the administrative costs of local taxation collected by Vítek and Pavel 
were still valid. Second, we checked if the most frequent argument about overly high general administrative costs per capita in small municipalities was really valid. Third, we tested the local service with the highest costs per capita - education. Because another very expensive service - waste management - was recently evaluated by Soukopová (2016) the data obtained should be representative and sufficient for conclusions.

The analysed data are from all municipalities in the South Moravian Region, the second largest region in the Czech Republic. It has 673 municipalities with a total of 1,173 thousand people, i.e. $11.1 \%$ of all inhabitants in the Czech Republic as of 2014. The data for all 673 municipalities are processed for the areas of general administrative costs and education. But when calculating the administrative costs of local taxation (collection of local taxes and fees), we analyse data for only 140 municipalities in the South Moravian Region, because the cost data for this analysis are not publicly available (there are no such statistics) and they had to be identified first (also by using a questionnaire survey). The questionnaire was sent to all municipalities in the region, but it was filled in by only 140 municipalities. Therefore, the cost analysis of local fees is limited to this number. The questionnaire survey involved municipalities of all size categories. Their distribution is shown in Table 2.

Table 2

Number of municipalities in the South Moravian Region by population-size category and municipalities involved in analysing the administrative costs of local taxation

\begin{tabular}{|l|c|c|c|}
\hline $\begin{array}{c}\text { Size category of } \\
\text { municipalities } \\
\text { (population) }\end{array}$ & $\begin{array}{c}\text { Number of } \\
\text { municipalities in } \\
\text { category }\end{array}$ & $\begin{array}{c}\text { Number of } \\
\text { municipalities } \\
\text { involved in } \\
\text { research }\end{array}$ & $\begin{array}{c}\text { \% of the total number } \\
\text { of municipalities in the } \\
\text { size category }\end{array}$ \\
\hline $1-199$ & 111 & 26 & 23.4 \\
\hline $200-499$ & 191 & 34 & 17.8 \\
\hline $500-999$ & 182 & 38 & 20.9 \\
\hline $1,000-1,999$ & 104 & 14 & 13.5 \\
\hline $2,000-4,999$ & 62 & 14 & 22.6 \\
\hline $5,000-9,999$ & 13 & 7 & 53.8 \\
\hline $10,000-19,999$ & 4 & 3 & 75.0 \\
\hline $20,000-49,999$ & 5 & 3 & 60.0 \\
\hline $50,000-99,999$ & 0 & 0 & 0.0 \\
\hline More than 100,000 & 1 & 1 & 100.0 \\
\hline Total & 673 & 140 & 20.8 \\
\hline
\end{tabular}

Source: Authors 
The empirical analysis of scale is based on a statistical estimation of an average cost of production. Data were analysed from the year 2014.

Cost on the public-service delivery is obtained from information portal MONITOR, administered by the Ministry of Finance of the Czech Republic and also from a questionnaire survey for the cost of collecting local fees. Data are based on the Czech budget classifications and recorded on a cash basis. The current prices are used.

\subsection{Data about costs of public services}

As mentioned above, the following public services were chosen for the cost analysis - preschool and elementary education (including education for disabled and physically handicapped children provided by municipalities), collection and administration of local fees and local administration. Investment expenditures of municipalities are not included, which are considered extraordinary expenses in this analysis and are predominantly connected with factors other than population size.

The process of cost-function identification of the collection of local fees is based on a previous analysis conducted by Vítek and Pavel (in Pudil et al. 2004). This study uses the method of comparing the volume of administrative cost of taxes and local fees per equivalent employee in the Czech Republic. It determines the percentage of employee working time that the employee spends with the agenda of local taxes and fees. It is used as a conversion factor for total costs incurred on the agenda of local fees at the municipal office.

Total administrative costs of collection and administration of local fees contain labour costs and running costs of the municipal office (authority). Labour costs include super-gross salaries of employees dealing with the agenda of local fees; employees dealing with other agendas in delegated and independent competences and carrying out supportive activities for the first group of employees; and the salaries of overhead employees of the municipal office (authority). Their activities have nothing to do with local fees. These data and also information about the number of employees in the municipal office were obtained from the questionnaire survey. Running costs contain non-investment costs of the municipal office (authority). After consultation with accountants and employees of selected municipalities financial data were downloaded about the expenditure of municipalities. They belong to class 6 - "General public administration and services", section 6171 - "Activities of local administration" according to the Czech budget classification and to paragraph 5137-5172.

Preschool and elementary education is a typical example of a public service mostly funded from the municipal budget in the Czech Republic. Other services, e.g. culture, sports or environmental protection are often funded by a combination of public funding and other financial sources. And costs for their delivery are significantly influenced by other factors - political decision, the structure of the 
municipal grant programmes or the existence of relevant facilities in the municipality. The financial data about preschool and primary education belongs to class 3 - "Services for citizens", sections 3111-3143; and to paragraph 5011-5499 if they are in the municipal budget.

Local administration includes all administrative activities of employees of municipal authorities relating to the delegated and independent competences. The financial data about local administration belongs to class 6 - "General public administration and services", section 6171 - "Activities of local administration" according to the Czech budget classification and to paragraph 5011-5499 if they are in the municipal budget.

\subsection{Regression analysis}

The tool for quantitative analysis was the linear regression model. The selection of the appropriate type of regression function should be based on economic criteria and existing economic theory. The most important assumption in theory about economies of scale is the progression of costs of public-service delivery in response to changes in population (or in number of clients of the services); and the U-shape that shows this dependence. These assumptions correspond with a polynomial (quadratic) function (of the first order).

Analyses of other authors most often use a simple linear regression function of the form:

$$
E_{j}=f\left(P_{j}, P_{j}^{2}, \varepsilon_{j}\right)
$$

where $E j$ is expenditure per capita on the selected service of local government in municipality $j . P$ is population of municipality $j$. The random error term $\varepsilon_{i}$ captures an unexplained variation.

The dependent variable was expenditures per capita, and the independent variable was municipality size (number of inhabitants). The population level was set as an explanatory variable for exploring whether the municipality size affects expenditure levels for the examined public services.

However, no specific type of linear regression function (polynomial or hyperbolic) is chosen for the thesis. This procedure was chosen because of the achievement of the greatest possible degree of accuracy in determining the regression function, to find the best interleaving of data by curve and the highest coefficient of determination. At the beginning, the regression model included all possible transformations of explanatory variables. After calculating the regression equation, the statistical significance of regression coefficients was found. Based on the test results the transformation of explanatory variables was excluded whose coefficient was insignificant. This process was repeated until the resulting regression function had all 
coefficients that were statistically significant. Therefore, each tested service has its own regression curve.

Since other factors may influence the cost of selected local services, the other explanatory variables are also included in regression analyses. Factors that influence the incomes and expenditures of municipalities on the basis of law or other legal (municipal) regulations were selected for each analysed service. These are the characteristics typical for Czech municipalities. For local fees, it is the number of fees levied in the municipality. For general administration it is population density, existence of a school and/or health centre, the number of parts in the municipality, the type of municipality according to the extent of the delegated competences and the status of the municipality.

The regression model for education included also the ratio of children and pupils to the number of inhabitants in the municipality and the population density. But in the case of the South Moravian region, both added explanatory variables for education proved to be insignificant. Therefore, the final model only contains a population variable.

\section{Results}

In this part, we provide the results of our analyses for all three selected areas using simple descriptions in the tables and the results from regression in tables.

\subsection{Administrative costs of local taxation}

The basic information is provided in Table 3. In terms of average costs, the lowest figure is for municipalities between 500 and 1,000 inhabitants. However, the median costs indicate that many other municipalities up to 5,000 inhabitants can be rather cost-effective.

The results of the regression analysis are shown in Table 4 . The other explanatory variable included is the number of fees that are collected in the municipality. 96 per cent of municipalities collect a fee for dogs and for waste, or at least one of them. The bigger the municipality, the greater the possibility of collecting fees. With the increasing number of inhabitants, the number of fees increases. More than two fees are levied by most municipalities with more than 600 inhabitants. 
Table 3

Administrative costs per capita of local taxation by population-size categories of municipalities, South Moravian Region, 2014

\begin{tabular}{|c|c|c|c|c|}
\hline $\begin{array}{c}\text { Municipality- } \\
\text { size category }\end{array}$ & $\begin{array}{c}\text { Average cost } \\
\text { (CZK) }\end{array}$ & $\begin{array}{c}\text { Median cost } \\
\text { (CZK) }\end{array}$ & $\begin{array}{c}\text { St. deviation } \\
\text { (CZK) }\end{array}$ & Count \\
\hline$<199$ & 232.93 & 146.91 & 152.04 & 23 \\
\hline $200-499$ & 185.60 & 86.24 & 352.00 & 36 \\
\hline $500-999$ & 51.83 & 42.67 & 33.61 & 37 \\
\hline $1,000-1,999$ & 62.87 & 40.91 & 55.60 & 15 \\
\hline $2,000-4,999$ & 208.64 & 69.29 & 497.18 & 15 \\
\hline $5,000-9,999$ & 561.63 & 505.62 & 164.84 & 7 \\
\hline $10,000-19,999$ & 554.24 & 555.76 & 67.80 & 3 \\
\hline $20,000-49,999$ & 859.10 & 908.72 & 597.40 & 3 \\
\hline $50,000-99,999$ & - & - & - & 0 \\
\hline$>100,000$ & 819.99 & - & - & 1 \\
\hline Total & 188.53 & 76.21 & 307.85 & 140 \\
\hline
\end{tabular}

Source: Authors

\section{Table 4}

Results of the regression model regarding the influence of the number of inhabitants and the number of fees on administration costs of collecting local fees,

$2014(n=140)$

\begin{tabular}{|l|c|c|c|c|c|}
\hline Variable & Estimate & Std. Error & t-ratio & p-value & \\
\hline const & 671.529 & 140.175 & 2.8127 & 0.0057 & $* * *$ \\
\hline Inhabit & 0.04386 & 0.00792016 & 7.1720 & $<0.0001$ & $* * *$ \\
\hline Inhabit2 & $-4.5634 \mathrm{e}-07$ & $1.20287 \mathrm{e}-07$ & -5.2243 & $<0.0001$ & $* * *$ \\
\hline Fees & -319.488 & 75.356 & -2.0864 & 0.0388 & $* *$ \\
\hline Fees2 & 38.97 & 9.23613 & 1.8237 & 0.0704 & $*$ \\
\hline Adjusted $\mathrm{R}^{2}$ & 0.30277 & & & & \\
\hline
\end{tabular}

Note: ${ }^{\star * \star}$ indicate statistical significance at the 1 per-cent significance level, ${ }^{\star \star}$ at the 5 per-cent significance level, ${ }^{*}$ at the 10 per-cent significance level

Source: Authors

The results of regression analysis show that population growth also raises the cost of collecting local fees. But it is only a tenth of a Czech crown. While respecting economies-of-scale theory, it can be argued that the relationship described above may have a non-linear nature for some population interval. With more significant population growth, administrative costs fall. This is affected by the Inhabit2 variable. It has a coefficient that is estimated to be negative. But beyond the limit of 
about 1,000 inhabitants, this cost affects changes and there is a renewed increase in costs. It can be concluded that there is a relationship between the number of inhabitants and the administrative costs of collecting local fees.

However, the linear increase in number of collecting local fees contributes significantly to a reduction in the administrative costs of collecting them. But if the number of fees does not grow linearly, the trend is reversed, and there is an increase in costs.

\subsection{Pre-school and elementary education}

The basic information is provided in Table 5. In terms of average costs, the lowest figure is for municipalities up to 200 inhabitants. However, this is a misleading finding, as most of these small villages do not deliver educational services. The differences in the average figures for all other categories are not large, and they range from 1,300 to 1,500 CZK per capita.

Table 5

Cost per capita of preschool and primary education by population-size categories of municipalities, South Moravian Region, 2014

\begin{tabular}{|c|c|c|c|c|}
\hline $\begin{array}{c}\text { Municipality- } \\
\text { size category }\end{array}$ & $\begin{array}{c}\text { Average cost } \\
\text { (CZK) }\end{array}$ & $\begin{array}{c}\text { Median cost } \\
\text { (CZK) }\end{array}$ & $\begin{array}{c}\text { St. deviation } \\
\text { (CZK) }\end{array}$ & Count \\
\hline$<199$ & 222.22 & 0.00 & $1,506.54$ & 111 \\
\hline $200-499$ & 625.75 & 85.96 & 968.80 & 189 \\
\hline $500-999$ & $1,416.45$ & $1,156.29$ & 982.59 & 185 \\
\hline $1,000-1,999$ & $1,678.68$ & $1,493.79$ & 826.40 & 102 \\
\hline $2,000-4,999$ & $1,534.85$ & $1,390.96$ & 633.92 & 62 \\
\hline $5,000-9,999$ & $2,106.95$ & $1,487.59$ & $1,826.04$ & 13 \\
\hline $10,000-19,999$ & $1,315.75$ & $1,375.33$ & 270.56 & 4 \\
\hline $20,000-49,999$ & $1,524.62$ & $1,500.25$ & 181.41 & 5 \\
\hline $50,000-99,999$ & - & - & - & - \\
\hline$>100,000$ & $1,349.72$ & - & - & 1 \\
\hline Total & $1,061.00$ & 917.52 & $1,185.71$ & 672 \\
\hline
\end{tabular}

Source: Authors

The results of regression analysis are shown in Table 6. Only 439 municipalities are included in the analysis. The reason is that municipalities up to 200 inhabitants do not usually have any school facility, especially for financial reasons and because of a lack of children to fill school classes. These municipalities have no or no minimum costs in pre-school and school education. This was caused by the amendment to the Act on Budgetary Allocation of Tax Revenues in 2013, which changed 
the way of providing a contribution to the education area at the municipal level. By 2014, the cost distribution at the municipal level was different.

\section{Table 6}

Results of the regression model regarding the influence of the number of inhabitants on costs of preschool and primary education, $2014(\mathrm{n}=439)$

\begin{tabular}{|l|c|c|c|c|c|}
\hline \multicolumn{1}{|c|}{ Variable } & Estimate & Std. Error & t-ratio & p-value & \\
\hline const & -2512.61 & 308.195 & -8.1527 & $<0.0001$ & $* * *$ \\
\hline Inhabit & -0.0880017 & 0.0231176 & -3.8067 & 0.0002 & $* * *$ \\
\hline 1/Inhabit & 577.977 & 50.7564 & 11.3873 & $<0.0001$ & $* * *$ \\
\hline Sq_inhabit & $2.0818 \mathrm{e}-07$ & $6.00703 \mathrm{e}-08$ & 3.4656 & 0.0006 & $* * *$ \\
\hline Adjusted $\mathrm{R}^{2}$ & 0.186093 & & & & \\
\hline
\end{tabular}

Note: ${ }^{* *}$ indicate statistical significance at the 1 per-cent significance level

Source: Authors

The results of the regression model for education show that there is a relationship between the number of inhabitants and costs of service. Only the coefficient of variable "inhabitants" has proved to be significant. According to the results, a small population means a significant increase in costs. A higher population, for example about 1,000 inhabitants, means a gradual reduction in costs.

However, the coefficient of determination is very low. In addition, in the case of the South Moravian Region, additional explanatory variables were shown to be insignificant. This means that other factors that have not been included in the model influence the cost. This suggests that it is necessary to test other factors, for example the perceived quality of provided service, but especially the number and types of educational facilities in the municipality (we still feel that the cost-minimisation method is appropriate for this service because of the existence of the national standard).

\subsection{General administration}

Political rhetoric and some empirical studies have criticised small municipalities for overly high administrative costs. However, our data do not sufficiently confirm this. Table 7 indicates that costs initially decrease, but start to increase very soon for municipalities over 2,000 inhabitants. 


\section{Table 7}

Average cost per capita on general administration in municipalities in the South Moravian Region, 2014

\begin{tabular}{|l|c|c|c|c|}
\hline $\begin{array}{c}\text { Municipality-size } \\
\text { category }\end{array}$ & $\begin{array}{c}\text { Average cost } \\
\text { (CZK) }\end{array}$ & $\begin{array}{c}\text { Median cost } \\
\text { (CZK) }\end{array}$ & $\begin{array}{c}\text { St. deviation } \\
\text { (CZK) }\end{array}$ & Count \\
\hline$<199$ & $2,579.67$ & $2,394.66$ & $1,721.34$ & 111 \\
\hline $200-499$ & $2,079.40$ & $1,823.64$ & $1,131.18$ & 189 \\
\hline $500-999$ & $1,711.67$ & $1,549.81$ & 827.39 & 185 \\
\hline $1,000-1,999$ & $1,498.22$ & $1,360.92$ & 477.92 & 102 \\
\hline $2,000-4,999$ & $1,995.84$ & $1,720.72$ & $1,556.80$ & 62 \\
\hline $5,000-9,999$ & 4.671 .59 & $4,508.85$ & 2.284 .53 & 13 \\
\hline $10,000-19,999$ & $4,960.25$ & $5,106.60$ & $1,375.63$ & 4 \\
\hline $20,000-49,999$ & $3,789.95$ & $3,743.51$ & 392.09 & 5 \\
\hline $50,000-99,999$ & - & - & - & - \\
\hline$>100,000$ & $3,391.63$ & - & - & 1 \\
\hline Total & $2,094.14$ & $1,717.00$ & $1,335.97$ & 672 \\
\hline
\end{tabular}

Source: Authors

The results of regression analysis are shown in Table 8.

Table 8

Results of the regression model regarding the influence of the number of inhabitants on costs of general administration, $2014(n=672)$

\begin{tabular}{|c|c|c|c|c|c|}
\hline Variable & Estimate & Std. Error & t-ratio & p-value & \\
\hline const & 4520.99 & 688.881 & 6.5628 & $<0.0001$ & $* * *$ \\
\hline Inhabit & -0.0542647 & 0.0256303 & -2.1172 & 0.0346 & $* *$ \\
\hline Parts of mun & -235.877 & 73.7393 & -3.1988 & 0.0014 & $* * *$ \\
\hline School & 815.431 & 399.421 & 2.0415 & 0.0416 & $* *$ \\
\hline Health centre & 250.967 & 125.772 & 1.9954 & 0.0464 & $* *$ \\
\hline Town/statutory & 437.162 & 122.109 & 3.5801 & 0.0004 & $* * *$ \\
\hline Authorised mun & 868.792 & 342.926 & 2.5335 & 0.0115 & $* *$ \\
\hline Extented comp & 4163.39 & 456.798 & 9.1143 & $<0.0001$ & $* * *$ \\
\hline I/inhabit & -558.451 & 72.0574 & -7.7501 & $<0.0001$ & $* * *$ \\
\hline I/school & -1600.44 & 746.587 & -2.1437 & 0.0324 & $* *$ \\
\hline sq_parts of mun & 13.0057 & 5.11503 & 2.5426 & 0.0112 & $* *$ \\
\hline Adjusted $\mathrm{R}^{2}$ & 0.332228 & & & & \\
\hline
\end{tabular}

Note: ${ }^{\star * \star}$ indicate statistical significance at the 1 per-cent significance level, ${ }^{\star *}$ at the 5 per-cent significance level, ${ }^{\star}$ at the 10 per-cent significance level

Source: Authors 
The results of the regression model for general administration show that there is a relationship between the number of inhabitants and costs of service. It has a coefficient for all significant transformations that is estimated to be negative. However, the existence of a school or a health-care facility is a major factor. According to the model, the extent of the delegated powers exercised by the municipality have the greatest impact on costs.

Also, according to the results the demonstration of economies of scale is problematic in this case, and other variables need to be examined. The regression model again indicates that the number of inhabitants may not be the best explanatory factor for the average general-administration costs in municipalities.

\section{Discussion and Conclusions}

The results of the analysis seem to confirm two core facts, established by most previous studies (see, for example, Byrnes and Dollery 2002):

a. cost curves have different shapes for different local services and functions, with different minimums,

b. not all local public services and functions can be connected with economies of scale.

Concerning the partial results of our study, we first did not fully confirm the calculations of Vítek and Pavel (in Pudil et al. 2004) for the administrative costs of local taxation. The common result is the finding that the average costs per capita are higher in small municipalities (up to 400 inhabitants); however, our data also indicate that these costs do not decrease for larger units as proposed by Vítek and Pavel - their sample may have been too small.

It is very difficult to confirm the existence of economies of scale for municipal educational services, as was shown in previous studies (especially Soukopová et al. 2014). Existing information suggests that average cost data are insufficient. It is necessary to perform a detailed analysis, especially with a focus on homogeneity of services (see also Houlberg and Møler 2001; Blom-Hansen 2004; Houlberg 2010; Montén and Thater 2011).

Our results concerning the cost of general administration are inconclusive, similarly to existing literature, in which some studies show certain evidence (see, for example, Hansen et al. 2014), but others show no evidence of economies of scale (Holcombe and Williams 2009) or even diseconomies of scale (Drew et al. 2012). More realistic data can be obtained only via more comprehensive analysis involving differences in institutional settings, tasks, local autonomy, etc. (see, for example, Houlberg 2010). However, our data at least indicate that the typical political rhetoric about administration in small municipalities being too expensive may not be evidence-based. 
Our findings and findings from other studies from the Czech environment (see also Soukopová et al. 2016) indicate that the existence of too small municipalities in the Czech Republic may be "economically inefficient". Small municipalities (up to 1,000 inhabitants) likely provide public services at higher costs than municipalities with larger populations.

What should these findings mean for the reform of territorial structures of municipalities in the Czech Republic? In the Czech Republic, due to the negative experiences from the period before 1989, there is still wide disagreement with amalgamation; therefore, other solutions should be tested, at least in the shortterm perspective.

The active promotion of inter-municipal cooperation seems to be the most important solution. In the Czech Republic, inter-municipal cooperation is a relatively successful tool. Many municipalities understand that they can achieve their goals more easily through cooperation. Moreover, the efficiency of inter-municipal cooperation is confirmed by existing studies (see, for example, Soukopová 2016). Positive results from cooperation may even lead to voluntary upscaling in the long term. The state should do much more to promote cooperative initiatives and remove existing administrative and financial requirements connected especially with formal forms of cooperation. It would be feasible to cope with low awareness among inhabitants and other stakeholders about inter-municipal cooperation and its benefits. For example, in France, where inter-municipal cooperation is highly developed, most citizens consider inter-municipal cooperation to be the best means of managing garbage collection, transport, water supply, sanitation etc.; people also prefer inter-municipal cooperation for environmental protection, housing and social services (see, for example, Hertzog 2010).

\section{Acknowledgements}

This research was completed with support from the research project APVV-150306: Collaboration activities of the local self-governments and measuring their effectiveness and efficiency, with support from the research project Performance Management in Public Administration: Theory and Practice in the Czech Republic and Other CEE Countries', ID (CEP) GA16-13119S.

\section{References}

Allan, Percy. 2003. "Why Smaller Councils Make Sense." Australian Journal of Public Administration 62, 74-81.

Alt, James E. 1971. "Some Social and Political Correlates of County Borough Expenditures." British Journal of Political Science 1, 49-62. 
Appelbaum, Richard P. and Ross Follett. 1978. "Size, Growth, and Urban Life A Study of Medium-Sized American Cities." Urban Affairs Review 14, 139-168.

Baldersheim, Harald and Lawrence Rose. 2008. A Comparative Analysis of Territorial Choice in Europe. Oslo: Political Institute.

Blom-Hansen, Jens. 2004. "Stordriftsfordele i den kommunale serviceproduktion? Skoleområdet som eksempel." In Jens Blom-Hansen, Asbjørn Sonne Norgaard and Thomas Pallesen (eds). Politisk Ukorrekt. Århus Universitetsforlag, $250-274$.

Bours, Adriann. 1993. "Management, Tiers, Size and Amalgamations of Local Government." In Robert Bennett (ed.). Local Government in the New Europe. London: Belhaven, 130-163.

Bovaird, Tony and Elke Löffler. 2003. "Evaluating the Quality of Public Governance: Indicators, Models and Methodologies." International Review of Administrative Sciences 69, 313-328.

Boyne, A. George. 1995. "Population Size and Economies of Scale in Local Government." Policy and Politics 23, 213-222.

Byrnes, Joel and Bryan Dollery. 2002. "Do Economies of Scale Exist in Australian Local Government? A Review of the Research Evidence." Urban Policy and Research 20, 391-414.

Coase, H. Ronald. 1937. “The Nature of the Firm." Economica 4, 386-405.

Czech Statistical Office. 2016. Malý lexikon obcí ČR 2015. Available at https://www. czso.cz/csu/czso/maly-lexikon-obci-ceske-republiky-2015 (last accessed 20 June 2016).

Dahl, R. Allan and Edward R. Tufte. 1973. Size and Democracy. Stanford: Stanford University Press.

Davies, Bleddyn. 1971. Variations in Services for the Aged: A Causal Analysis (No. 40). London: G. Bell and Sons.

Denters, Bas. 2002. "Size and Political Trust: Evidence from Denmark, the Netherlands, Norway, and the United Kingdom." Environment and Planning C: Government and Policy 20, 793-812.

Dollery, Bryan, Joel Byrnes and Lin Crase. 2008. "Australian Local Government Amalgamation: A Conceptual of Analysis Population Size and Scale Economies in Municipal Service Provision." Australasian Journal of Regional Studies $14,167$.

Dollery, Bryan, and Euan Fleming. 2006. "A Conceptual Note on Scale Economies, Size Economies and Scope Economies in Australian Local Government." Urban Policy and Research 24, 271-282. 
Drew, Joseph, Andy Kortt and Bryan Dollery. 2012. "Economies of Scale and Local Government Expenditure: Evidence from Australia." Administration \& Society 20, 1-22.

Faulk, Dagney Gail and Joel Hicks. 2011. Local Government Consolidation in the United States. New York: Cambria Press.

Foster, D. Christopher, Richard Jackman and Morris Perlman. 1980. Local Government Finance in a Unitary State. London: George Allen and Unwin.

Fox, William F. and Tami Gurley-Calvez. 2006. "Will Consolidation Improve SubNational Governments?” World Bank Policy Research Working Paper 3913.

Galvasová, Iveta et al. 2007. Identifikace kompetencí zatěžujících výkon veřejné správy se zvláštním přihlédnutím k malým obcím. Available at http://www. mvcr.cz/clanek/identifikace-kompetenci-zatezujicich-vykon-verejne-spravy-se-zvlastnim-prihlednutim-k-malym-obcim-1-etapa.aspx (ast accessed 15 August 2016).

Goldsmith, M. and Lawrence E. Rose. 2000. "Constituency, Size and Electoral Politics: A Comparison of Patterns at Local Elections in Norway and the UK." Paper presented at the IPSA $18^{\text {th }}$ World Congress, Quebec, Canada.

Hampl, Martin and Jan Müller. 1998. "Jsou obce v České republice př́liš malé." Geografie - Sbornik ČGS 103, 1-12.

Hansen, Sune Welling, Kurt Houlberg and Lene Holm Pedersen. 2014. "Do Municipal Mergers Improve Fiscal Outcomes?" Scandinavian Political Studies 37, 196-214.

Hertzog, Robert. 2010. "Inter-municipal co-operation: a viable alternative to territorial amalgamation?" In Pawel Swianiewicz (ed.). Territorial Consolidation Reforms in Europe. Budapest: Local Government and Public Service Reform Initiative, 289-312.

Hirsch, Z. Werner. 1959. "Expenditure Implications of Metropolitan Growth and Consolidation." The Review of Economics and Statistics 1959, 232-241.

Holcombe, G. Randall and DeEdgra W. Williams. 2009. "Are there Economies of Scale in Municipal Government Expenditures?" Public Finance and Management 9, 416.

Houlberg, Kurt. 1995. "Kommunale stordriftsfordele: Myte eller realitet?" Nordisk administrativt tidsskrift 76, 65-88.

Houlberg, Kurt. 2010. "Municipal Size, Economy, and Democracy." In Pawel Swianiewicz (ed.). Territorial Consolidation Reforms in Europe. Budapest: Local Government and Public Service Reform Initiative, 309-331. 
Houlberg, Kurt and I. L. Møller. 2001. "Kommunestørrelse og udgiftsniveau: Er der en sammenhæng?" In R. Norstrand and N. Groes (eds). Kommunestyrets fremtid. København: Akf Forlaget, 185-198.

Hutcheson, John D. and James E. Prather. 1979. "Economy of Scale or Bureaucratic Entropy? Implications for Metropolitan Governmental Reorganization." Urban Affairs Review 15, 164-182.

Keating, Michael. 1995. "Size, Efficiency and Democracy: Consolidation, Fragmentation and Public Choice." In D. Judge, G. Stoker. and H. Wollman (eds). Theories of Urban Politics. London: Sage, 117-134.

King, N. David. 1984. Fiscal Tiers: The Economics of Multi-Level Government. London: Allen \& Unwin.

Kushner, Joseph and David Siegel. 2003. "Citizens' Attitudes toward Municipal Amalgamation in Three Ontario Municipalities." Canadian Journal of Regional Science 26, 49-60.

Löffler, Elke. 2002. "Defining and Measuring Quality in Public Administration." In Joanne Caddy and Mirko Vintar (ed.). Building Better Quality Administration for the Public: Case Studies from Central and Eastern Europe. Bratislava: Nispacee 15-34.

Montén, Anna and Christian Thater. 2011. "Determinants of Efficiency in ChildCare Provision." FinanzArchiv: Public Finance Analysis 67, 378-403.

Mouritzen, Poul Erik. 1989. "City Size and Citizens' Satisfaction: Two Competing Theories Revisited." European Journal of Political Research 17, 661-688.

Mouritzen, Poul Erik. 1991. Den politiske cyklus. Aarhus: Politica.

Musgrave, Richard Abel and Peggy B. Musgrave. 1989. Public Finance in Theory and Practice. New York: McGraw/Hill, Inc.

Newton, Kenneth. 1982. "Is Small Really so Beautiful? Is Big Really so Ugly? Size, Effectiveness, and Democracy in Local Government." Political Studies 30, 190-206.

Nielsen, Hans Jorgen. 1981. "Size and Evaluation of Government: Danish Attitudes towards Politics at Multiple Levels of Government." European Journal of Political Research 9, 47-60.

Oates, Wallace E. 1972. Fiscal Federalism. Chicago: Books.

Oates, Wallace E. 1999. “An Essay on Fiscal Federalism." Journal of Economic Literature 37, 1120-1149. 
OECD. 2004. OECD territorial reviews: The Czech Republic 2004. Available at http:// www.oecd-ilibrary.org/urban-rural-and-regional-development/oecd-territorial-reviews-czech-republic-2004_9789264106413-en (last accessed 27 June 2016).

Pudil, Pavel et al. 2004. Zdanění a efektivnost. Praha: Eurolex Bohemia.

Rose, Lawrence E. 2002. "Municipal Size and Local Nonelectoral Participation: Findings from Denmark, the Netherlands, and Norway." Environment and Planning C: Government and Policy 20, 829-851.

Sawyer, M. C. 1991. The Economics of Industries and Firms: Theories, Evidence and Policy. London: Routledge.

Schofield, John A. 1978. "Determinants of Urban Service Expenditures: Fire and Social Services." Local Government Studies 4, 65-80.

Sharpe, J. 1995. "Local Government: Size, Efficiency and Citizen Participation." In Michael Martins (ed.). The Size of Municipalities, Efficiency and Citizen Participation. Strasbourg: Local and Regional Authorities in Europe, Council of Europe, 56.

Stigler, George J. 1958. "Economies of Scale." The Journal of Political Economy 1958, 54.

Soukopová, Jana. 2016. Efektivnost výdajů obcí na nakládání sodpady. Habilitation thesis, Masaryk University, Brno.

Soukopová, Jana et al. 2014. "Municipality Size and Local Public Services: Do Economies of Scale Exist?" NISPAcee Journal of Public Administration and Policy 7, 151-171.

Soukopová, Jana et al. 2016. "Factors Influencing the Efficiency and Effectiveness of Municipal Waste Management Expenditure." Lex Localis 14, 359.

Swianiewicz, Pawel. 2002. "Size of Local Government, Local Democracy and Efficiency in Delivery of Local Services: International Context and Theoretical Framework." In Pawel Swianiewicz (ed.). Consolidation or Fragmentation: The Size of Local Governments in Central and Eastern Europe. Budapest: Local Government and Public Service Reform Initiative, 1-29.

Swianiewicz, Pawel. 2010. "If Territorial Fragmentation is a Problem, is Amalgamation a Solution? An East European Perspective." Local Government Studies 36, 183-203.

Swianiewicz, Pawel. 2014. "An Empirical Typology of Local Government Systems in Eastern Europe." Local Government Studies 40, 292-311.

Tiebout, Charles M. 1956. "A Pure Theory of Local Expenditures." The Journal of Political Economy 64, 416-424. 